\title{
COOPERATION AND INTEGRATION IN THE REGION
}

\author{
Alexander Valerievich Nikitin ${ }^{1}$ \\ O.Yu. Antsiferova ${ }^{2}$
}

\begin{abstract}
The study aims at substantiating the convergence of the cooperation and integration principles when transforming the social division of labor, and, based on this, grounding the strategic parameters for developing sectors of the agro-industrial complex (AIC) in the region. In accordance with it, the necessity of developing a strategy that takes into account the inertial, local innovation and systemic innovative development scenarios has been substantiated. The features of each scenario related to improving the production as well meeting regional needs in these products have been determined. Forecast scenarios on developing agricultural sectors have been analyzed. According to this analysis, the potential formed in the Tambov Region is sufficient for implementing the innovative approach to solving technological problems on improving the production efficiency.
\end{abstract}

Keywords: cooperation, integration, interaction, region, strategic parameters, forecast, development scenarios

\section{Introduction}

Cooperation as one of the forms of the social division of labor is a complex multifunctional category that can be defined as a set of voluntary associations of agricultural producers organized through share participation in various areas of economic activity with the goal of contributing to the improvement of the life and work of their members, and along with the economic activity, being socially orientated. In other words, cooperation is revealed by a certain system of elements represented by organizational and technical, organizational and economic, institutional and socio-constitutional functions.

When studying the development of cooperation and integration, it is necessary to distinguish between the

Federal State Budgetary Educational Institution of Higher Education «Michurinsk State Agrarian University», ${ }^{1}$ Michurinsk, Russian Federation

Federal State Budgetary Educational Institution of Higher Education «Michurinsk State Agrarian University», ${ }^{2}$ Michurinsk, Russian Federation 
concepts of cooperation and integration process, cooperation and integration interaction, cooperation and integration interrelations.

The authors think that the term "interrelations", which is considered not only as the management of all resources in order to achieve a certain reaction of market participants (conclusion of transactions, joint transactions, receipt and distribution of profit), but also as creation, maintenance, development and termination of relations with market entities, must be considered as primary. In other words, interrelations can also exist without interaction.

The interrelations form an interaction and thus contribute to the formation and development of processes of all kinds where market entities participate and direct their future behavior (Fig. 1).

Figure 1. Categorical Apparatus of the Concepts "Interrelations", "Interaction", "Process" Used to Study Cooperation and Integration

Adapting the conceptual apparatus to the study of cooperation and integration, it is possible to characterize the cooperative and integration processes as structural transformations of the interrelations between the subjects of the agricultural market when they enter into cooperative and integration interaction.

In case of the positive variant of interaction, the vector of the concept "process" is the development interpreted as the irreversible qualitative change of the subject or the process associated with the complication or simplification of the production system, its adaptation to the changing environmental conditions.

The unification processes based on the social division of labor are implemented as a combination of various measures to combine the efforts of disparate and independently functioning entities of economic relations, including enterprises and organizations aimed at forming a coherent production and service system in order to ensure a more rational use of the entire production potential and achievement of higher production results of their activities, both general and individual.

This is in case of functioning of organizations based on interaction (Krivokora, 2006) when there is a problem on determining the form of functioning: what principles they are based on: cooperative or integration. The classical principles of cooperation are still the main advantage. However, when studying the system of principles, it is necessary to proceed from the fact that in time, 
depending on the types of cooperation, the role of some principles is transformed due to the development of social relations. In addition, new principles arise. According to the studies, the development of cooperation and integration processes in the agricultural sector of the economy is largely due to the formation of a system for the implementation of various types of interests which manifests the following:

- Institutional interests - by pursuing the state policy in the area of agricultural development, the formation of sustainable development of rural territories, the optimization of the system of intersectoral relations, the increase in tax deductions, and the efficient investment policy,

- Economic interests - by improving labor productivity, rationalization of the strategic planning system, the reproduction of the material and technical base, the formation of an efficient price mechanism, and material stimulation of labor,

- Land interests - by consolidating land with the efficient owner, the preservation of large land masses, the restoration of land fertility, environmentally friendly tillage,

- Property interests - by combining private property and a collective form of its use, the growth of property income, the increase in incremental equities and share value,

- Production interests - by modernizing means of production, coordinating the entrepreneurial activity, meeting the needs of the market in high quality environmentally friendly products and services, overcoming monopolism of large trading enterprises and organizations, and

- Social interests - by democratic governance, job security, creation of favorable conditions for the reproduction of labor resources, additional jobs.

However, according to the studies (Antsiferova, 2010; Chaliapin, Antsiferova, Myagkova, 2017; Tolstoshein, 2015), changes in the external environment where agricultural cooperatives function caused the need in searching for additional investments in order to develop production. Due to this, a number of consumer cooperatives that allow raising the capital from shareholders who are not members of the cooperative are formed.

They can include institutional investors and partners engaged in processing agricultural products or supplying agriculture with resources. This not only increases the capital, but also reduces transaction costs due to the 
coordination of activities along the production chain.

The more the cooperative as an economic organization is involved in market relations, the less is left for it to maintain equivalence in economic relations, both between its members and the cooperative itself and the external environment. This is explained by the fact that the market, through the prices, the financial and credit mechanism and other manifestations, has considerable impact on the nature of cooperative activities. The cooperative as an economic organization starts "alienating" from its members, and their interests come into certain contradictions. The search for optimal actions is influenced by mutually exclusive factors: on the one hand, the desire for the independent economic activity, and on the other hand, the compliance with cooperative principles. What may be beneficial for the cooperative becomes disadvantageous for its members, and vice versa.

In terms of organizational characteristics and the legal foundations of the activity, under modern conditions cooperatives have a number of special principles: profit distribution is proportional to labor (or economic) participation in the activity; and protective mechanisms against unfair management. The social orientation of cooperatives is manifested in the formation of solidarity relations, the creation of terms and conditions for the sustainable development of rural areas, and the improvement of the population's life quality. It is necessary to note that under modern conditions the pure form of cooperation and integration is quite rare in terms of the organization of production, and the boundaries between the principles and mechanisms of their functioning are erased. According to the authors, it is reasonable to single out the following general principles of cooperation and integration processes that indicate the transformation and convergence of the forms of labor division under study:

1. Integration and cooperation is a process of participants' interaction.

2. Participants can include both legal entities and individuals, including individual entrepreneurs.

3. Integration and cooperation take on a certain organizational form.

4. Integration and cooperation are characterized by consolidating funds, coordination of joint activities of its participants.

5. Participants in cooperation and integration have agreed goals. 
6. The legislation establishes cases of state regulation of both the creation and the activities of cooperated and integrated structures.

Indeed, the common motive for cooperation and integration is the effect achieved by accumulating means of production, expanding its scale, etc. As a result, intersectoral relations are optimized, large-scale business is developing, transaction costs are reduced, and product competitiveness is improved.

However, along with the objective commonality of the principles of cooperation and integration as forms of the social division of labor, there are undoubtedly functional features that make it possible to clearly distinguish between these concepts, both from the point of view of the economic theory and the features of functioning in the economy (Table 1).

Table 1. Comparative Characteristic Analysis of Cooperation and Integration

\begin{tabular}{|c|c|c|}
\hline Characteristics & Cooperation & Integration \\
\hline Meaning & \multicolumn{2}{|c|}{$\begin{array}{l}\text { Forms of organization and development of the social labor, } \\
\text { production }\end{array}$} \\
\hline Formation & $\begin{array}{l}\text { Combining the labor, capital } \\
\text { and production means that } \\
\text { have the same specialization }\end{array}$ & $\begin{array}{l}\text { Combination of the capital and } \\
\text { production means that are } \\
\text { different but having the common } \\
\text { production goal }\end{array}$ \\
\hline Subjects & $\begin{array}{l}\text { One-type subjects, rarely } \\
\text { subjects of different types }\end{array}$ & Subjects of different types \\
\hline $\begin{array}{l}\text { Basic principle of the } \\
\text { activity }\end{array}$ & $\begin{array}{l}\text { Equality; } \\
\text { Cooperation based on the } \\
\text { joint participation. }\end{array}$ & $\begin{array}{l}\text { Defining the leading element; } \\
\text { Cooperation based on the mutual } \\
\text { counterpart. }\end{array}$ \\
\hline Goal & $\begin{array}{l}\text { Obtaining benefits from } \\
\text { using the cooperation } \\
\text { advantages, meeting needs of } \\
\text { the cooperative members }\end{array}$ & $\begin{array}{l}\text { Obtaining benefits from using } \\
\text { integration advantages }\end{array}$ \\
\hline $\begin{array}{l}\text { Voting when making } \\
\text { decisions }\end{array}$ & One member - one vote & $\begin{array}{l}\text { One share }- \text { one vote } \\
\text { or one stake }- \text { one vote }\end{array}$ \\
\hline $\begin{array}{l}\text { Adaptability } \\
\text { agriculture }\end{array}$ & $\begin{array}{l}\text { It takes into account the } \\
\text { aptitude of the rural } \\
\text { population to the collective } \\
\text { labor based on equality. }\end{array}$ & $\begin{array}{l}\text { Relatively new form for the rural } \\
\text { area, considerable } \\
\text { commercialization of the activity }\end{array}$ \\
\hline Income & $\begin{array}{l}\text { Distributed depending on the } \\
\text { labor participation }\end{array}$ & $\begin{array}{l}\text { Distributed proportionally to the } \\
\text { invested capital }\end{array}$ \\
\hline
\end{tabular}


The need in the development of principles is caused not only by external, but also by internal changes that take place in the Russian cooperative movement:

- The need to raise investments for modernizing the Russian agriculture and conduct production on an innovative basis,

- The aspiration to expand the scope of activities, which in some cases is impossible without changing the principle of economic participation,

- Considerable weakening of state support, and

- Strengthening the impact of the hired administration, because in many cooperatives, management and control have passed from members to professionals, and priorities are determined by the professional training and interests of managerial personnel rather than by the interests and needs of members,

- The growth of "economic cooperation", i.e., cooperation of entrepreneurs,

- The search for additional financial resources that cause the loss of control by members to obtain the necessary funds,

- Distribution of common funds, expressed in the fact that a number of cooperatives alienate their property either in favor of other persons, or by transformation into a different legal form, and often such a "sale" is initiated by the cooperative's administration and, mainly, in its benefit, and

- The growing impact of the social economy concept, i.e., the concept of counterbalancing to large business by increasing social benefits to shareholders, which can cause serious harm to the cooperative movement that is distinguished by the autonomy and self-reliance.

Unfortunately, the basic principles of the cooperative movement cannot be fully implemented in the modern market economy.

Due to this, according to the authors, during the further development of the forms of social division of labor, the cooperation and integration principles come closer in a number of areas: saving transaction costs, complementarity of resources, eliminating inefficiencies, diversification of production, raising investments, which contributes to forming the economy of cooperatively integrated economic structures, including cluster type in the agricultural sector (Khaidukova, Araslanov, 2019; Bakinova et al., 2019; Mustafayeva et al., 2019; Zhildikbaeva et al., 2019).

Thus, integration and cooperation are not mutually exclusive, but 
complementary forms of division of labor that contribute to the rational use of the production and resource potential in agriculture, improvement of the competitiveness and efficient operation of cooperated and integrated structures, and optimizing the mechanism for bringing end products to the consumer.

Market relations that underlie the organization of all interconnections in the economic space suggest a different degree of uncertainty. Due to this, possible trends in the development of the situation can be diverse and must take into account the minimum requirement to ensure the stability of the production units functioning. This is what determines the need in using the scenario-based approach to grounding strategic development prospects. The development scenarios are not the plans that must be obligatorily implemented in a "pure form", but they set the limit values one must strive at every moment.

It is necessary to take into account that the strategic effect consists of the successful implementation of measures to improve production based on the expanded reproduction of a tactical nature, but it is not a mere sum of their effects. The time factor is of paramount importance in developing various branches of the AIC, especially cattle breeding. The food security of the region and the quality of people's life depend on how quickly the issue on the complete provision of the population with food in accordance with the medical standards is solved. Since the functioning of industries is determined by the characteristics of agricultural production, its development can be accelerated only on the basis of improving its management intensity.

In the future there are two types of development scenarios for industries inertial and innovational. The inertial scenario provides for maintaining of the current growth trends in the industry's economy, but, unfortunately, it does not imply the solution of its structural problems - eliminating threats to the exhaustive use of natural resources and the socio-economic crisis of rural territories (Antsiferova, 2010).

\section{Methods}

\section{General description}

The approach to the innovative development of sectors of the AIC involves the top priority improvement of the technical and technological base of industries by modernizing and partially updating them, improving production processes, transferring to the resource- 
saving and environmentally friendly technologies, improving mechanization, automating and computerizing production, diversifying agricultural production and reducing the environmental pressure. On the whole, this will contribute, on the one hand, to the improvement in labor productivity in agriculture, and, on the other hand, to the reduction in the severity of social problems in rural areas.

\section{Algorithm}

The main conditions for the implementation of the inertial development scenario include the following:

- Limited opportunities to raise large investments,

- Disability to introduce local innovations in production.

The conditions for implementing the innovational development scenario include the following:

- Highly qualified personnel or the possibility to attract it,

- Continuous monitoring of the development of innovative solutions,

- Availability of resource potential in the required volume, and
- Systematic implementation of innovations.

The selection of the scenario for the development of agricultural sectors is determined by the criterion of socioeconomic feasibility, as well as according to the analysis of the impact of stimulating and restraining factors on the production processes in the industry (Table 1). Moreover, the development forecast, regardless of its organizational and economic features, must necessarily take into account the technological specifics of the reproduction of the resource base in a certain industry.

\section{Results}

In accordance with the Strategy of Socio-Economic Development of the Tambov Region Until 2035, agricultural producers are challenged to improve crop production (grain - up to 6 million tons, sugar beet - 9 million tons) and livestock (milk - up to 525 thousand tons, meat - up to 1 million tons) by 2030 . This will allow agriculture to become the leading sector of the region's economy, and increase the production index up to $105.5 \%$ (Butylina, 2006).

Table 2. Restrictive and Stimulating Factors When Selecting Options for the Strategic Development of Agricultural Sectors (Through the Example of Dairy Cattle) 


\begin{tabular}{|c|c|c|c|}
\hline \multicolumn{2}{|c|}{ Inertial type of strategic development } & \multicolumn{2}{|c|}{ Innovational type of strategic development } \\
\hline $\begin{array}{l}\text { Restrictive factors of } \\
\text { selection }\end{array}$ & $\begin{array}{l}\text { Stimulating factors } \\
\text { of selection }\end{array}$ & $\begin{array}{l}\text { Restrictive factors of } \\
\text { selection }\end{array}$ & \begin{tabular}{|l|}
$\begin{array}{l}\text { Stimulating factors } \\
\text { of selection }\end{array}$ \\
\end{tabular} \\
\hline $\begin{array}{l}\text { - moderate economic } \\
\text { exchange imbalance, } \\
-\quad \text { limited own } \\
\text { resources, and } \\
\text { - high vulnerability } \\
\text { to internal or external } \\
\text { critical events. }\end{array}$ & $\begin{array}{l}\text {-the austerity } \\
\text { strategy } \\
\text { implemented by a } \\
\text { business entity, and } \\
\text { - the possibility of } \\
\text { expanding } \\
\text { modernization } \\
\text { measures over time }\end{array}$ & $\begin{array}{l}\text { - the lack of well- } \\
\text { defined mechanisms } \\
\text { for transferring } \\
\text { innovations to the } \\
\text { production sector, } \\
\text { - the lack of } \\
\text { mechanisms to } \\
\text { stimulate business } \\
\text { investments in the } \\
\text { development } \\
\text { advanced of } \\
\text { technologies, } \\
- \text { problems on the } \\
\text { investment support } \\
\text { of the industry are } \\
\text { partially solved, and } \\
- \text { low profitability of } \\
\text { the industry. }\end{array}$ & $\begin{array}{l}\text { - modeling the } \\
\text { organizational and } \\
\text { economic } \\
\text { development based } \\
\text { on a program- } \\
\text { targeted approach, } \\
- \text { enhancing risk } \\
\text { management } \\
\text { capabilities, } \\
- \text { state support for } \\
\text { technical re- } \\
\text { equipment, and } \\
\text { - the mechanism to } \\
\text { protect intellectual } \\
\text { property. }\end{array}$ \\
\hline
\end{tabular}

In the study, the degree of compliance of the forecast parameters for developing individual agricultural sectors in the region with their estimated values calculated on the basis of trend equations that take into account the preservation of process conditions was established. For example, in dairy cattle breeding there is a "gap" between the indicators calculated according to the trend equations and forecast values - livestock of forage-fed cows, total milk yield, and milk yield from one forage-fed cow. On average, the differences were $6.5 \%$ by cow productivity, $6 \%$ by cow livestock, and 1.2
$\%$ by the milk yield (Table 2 ) (Krivokora, 2006).

Thus, the calculations show that in the Tambov Region, when maintaining a stable orientation situation for the development of dairy cattle breeding and maintaining the import substitution policy, the provision of the region's population with milk and dairy products (in terms of basic fat content) in accordance with medical recommendations can be achieved by 2022 . However, if to take into account the concept of innovative development of the industry adopted in the region and involving the construction of 16 dairy complexes by using new technologies, and 
designed for 1,200 cows each (Butylina, 2006), then, according to the authors' calculations that provided for a linear trend in the development of dairy cattle breeding, in the region by 2025 dairy producers can "reach" the interregional level of import, and by 2030 they can have a wellestablished presence there.
However, according to the studies, producers may face such problems as the feasibility of increasing the sowing area and livestock of animals while achieving high crop yields and animal productivity, as well as the efficiency of using expensive equipment for reconstructed and modernized organizations.

Table 3. Correspondence of the Calculated and Forecast Parameters of Developing Dairy Cattle Breeding for the Long Term (for the Period Until 2030) in Agricultural Organizations and $\mathrm{P}(\mathrm{F}) \mathrm{H}$ of the Tambov Region*)

\begin{tabular}{|c|c|c|c|c|c|c|c|c|c|}
\hline \multirow[b]{2}{*}{ Indicators } & \multirow[b]{2}{*}{ Trend equation } & \multicolumn{2}{|c|}{2018} & \multicolumn{2}{|c|}{2020} & \multicolumn{2}{|c|}{2025} & \multicolumn{2}{|c|}{2030} \\
\hline & & $\frac{\vec{D}}{\frac{\vec{E}}{\vec{J}}}$ & 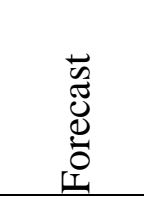 & $\frac{\vec{D}}{\frac{\vec{J}}{\vec{J}}}$ & 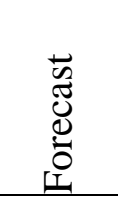 & $\frac{\vec{D}}{\frac{\vec{E}}{J}}$ & 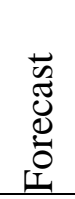 & $\frac{\vec{D}}{\frac{\vec{E}}{\vec{J}}}$ & 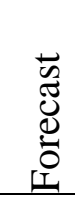 \\
\hline $\begin{array}{l}\text { Livestock of } \\
\text { forage-fed } \\
\text { cows, cows }\end{array}$ & $\mathrm{y}=59.1+3.28 * \mathrm{t}$ & 51.1 & 54.3 & 64.2 & 68.0 & 80.5 & - & 100.8 & - \\
\hline $\begin{array}{l}\text { Total milk } \\
\text { yield, thous. } \\
\text { dt }\end{array}$ & $\mathrm{y}=229.8+26.9 * t$ & 245.3 & 246.8 & 339.2 & 330 & 469 & - & 648.6 & - \\
\hline $\begin{array}{l}\text { Milk yield } \\
\text { from one } \\
\text { forage-fed } \\
\text { cow per year, } \\
\mathrm{kg}\end{array}$ & $\mathrm{y}=4,428+104 * t$ & 4793 & 5073.1 & 5278 & 4986 & 5827 & - & 6434 & - \\
\hline $\begin{array}{l}\text { Population of } \\
\text { the region, } \\
\text { thous. } \\
\text { persons }{ }^{1}\end{array}$ & - & $1,037$. & & 1,019 . & & 974.87 & & 937.58 & \\
\hline $\begin{array}{l}\text { Production } \\
\text { of milk as per } \\
\text { one citizen of } \\
\text { the region, } \\
\mathrm{kg}\end{array}$ & - & 236.5 & 238.0 & 332.8 & 323.8 & 481.1 & - & 691.8 & - \\
\hline $\begin{array}{l}\text { Consumption } \\
\text { of milk and } \\
\text { dairy }\end{array}$ & - & 165.6 & 166.6 & 266.3 & 259.0 & 408.9 & - & 622.6 & - \\
\hline
\end{tabular}


498

\begin{tabular}{|c|c|c|c|c|c|c|c|c|c|}
\hline $\begin{array}{l}\text { products (in } \\
\text { terms of milk } \\
\text { with the } \\
\text { basic fat } \\
\text { content) as } \\
\text { calculated } \\
\text { per one } \\
\text { citizen of the } \\
\text { region per } \\
\text { year, kg }\end{array}$ & & & & & & & & & \\
\hline $\begin{array}{l}\text { Degree of } \\
\text { milk diet, } \%\end{array}$ & - & 59.1 & 59.5 & 95.1 & 92.5 & 146.0 & - & 194.6 & - \\
\hline
\end{tabular}

${ }^{1}$ Calculation of the forecast size of the population in the Tambov Region (Ofitsialnyy sayt territorialnogo organa Federalnoy sluzhby gosudarstvennoy statistiki po Tambovskoy oblasti, n.d.)

In order to solve these problems, it is necessary to consider the correct organization of production processes and the possibility of selling agricultural products at high prices. While the first area - improving the efficiency of production entirely depends on intra-economic decisions and staff qualifications, the second one depends on the market conditions and is in no way dependent on even associative efforts of agricultural producers (Ksenofontov et al., 2008).

It is necessary to note that the preservation of the economic independence of the vast majority of agricultural market participants, on the one hand, provides freedom of choice to wholesalers who are buyers of this product, and, on the other hand, allows destructuring the raw materials bases of regional processing enterprises that due to the decrease in the population's solvency also have to optimize their own production program towards those types of products that are demanded on the retail market. In other words, under the modern crisis conditions, market mechanisms cannot regulate price proportions in the agricultural market, which requires the state intervention.

When determining strategic parameters for the development of agricultural production, many researchers use the scenario approach (Zakon Tambovskoy oblasti No. 246-Z, 2018). During the study, through the example of dairy cattle breeding in the Tambov Region, the authors grounded the parameters for developing this industry until 2030, taking into account three scenarios: inertial, local innovational, and system innovational.

When determining development parameters for each scenario, the rate of 
increasing milk and dairy production, as well as meeting regional needs in these products were taken into account.

The inertial scenario involves maintaining the pace of improving the productivity of cows and maintaining their livestock, the local innovational scenario means partial improvement of the production through the phased implementation of innovative solutions that, as a rule, cover individual technological operations, which, on the one hand, allows maintaining and increasing the achieved acceleration of the milk production increase, and, on the other hand, optimizing investments in industry facilities. The system innovational scenario provides for a complete renewal of the resource base of dairy cattle breeding by constructing complexes and farms that create the best microclimate in the livestock building, mechanization and automation of work processes, the use of cows with high genetic productivity potential (Krivokora, 2006).

Regarding the possibilities of meeting the needs of the population in milk and dairy products in full in accordance with the medical recommendations, it is necessary to note that due to regional milk resources they can be satisfied by 2025 . Due to the fact that, according to Tambovstat, the population of the region may decrease by $9 \%$, the Tambov Region may act as a seller of $55.4 \%$ of the milk produced in the interregional market (Fig. 1). However, until 2025 the region will be an active importer of dairy products due to the lack of its own production capacities (Antsiferova, Myagkova, 2015).

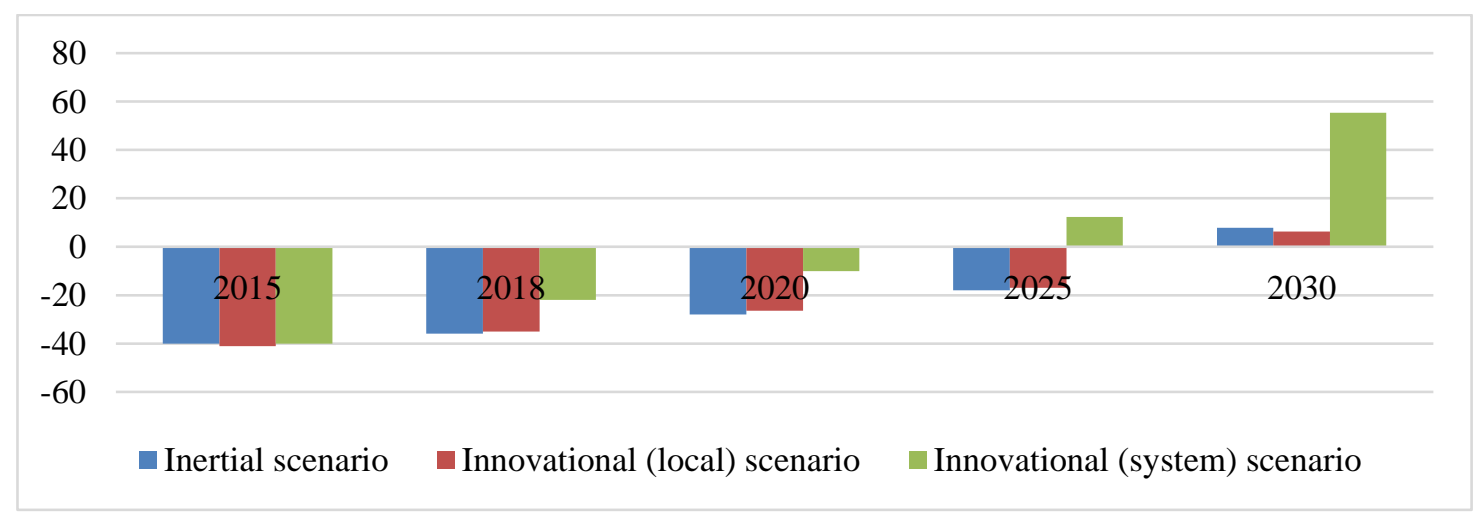

Figure 1. Forecast of Export of Milk Produced in the Tambov Region to the Interregional Market for the Period of 2018 - 2030 by Strategic Development Scenarios

At the same time, it is necessary to note that the adopted policy of the widespread industrial development of dairy cattle breeding in the regions with favorable 
climatic conditions makes it possible to supply processed milk (including dry) to the north of the country, or makes it seek reserves to participate in intense competition with many dairy plants in the Central Federal District.
With great probability (subject to recovering the population's solvency), the region's demand for milk will have increased by $46.3 \%$ by 2030 as compared to 2015 , which is the ground for creating an adequate production base for this product (Fig. 2).

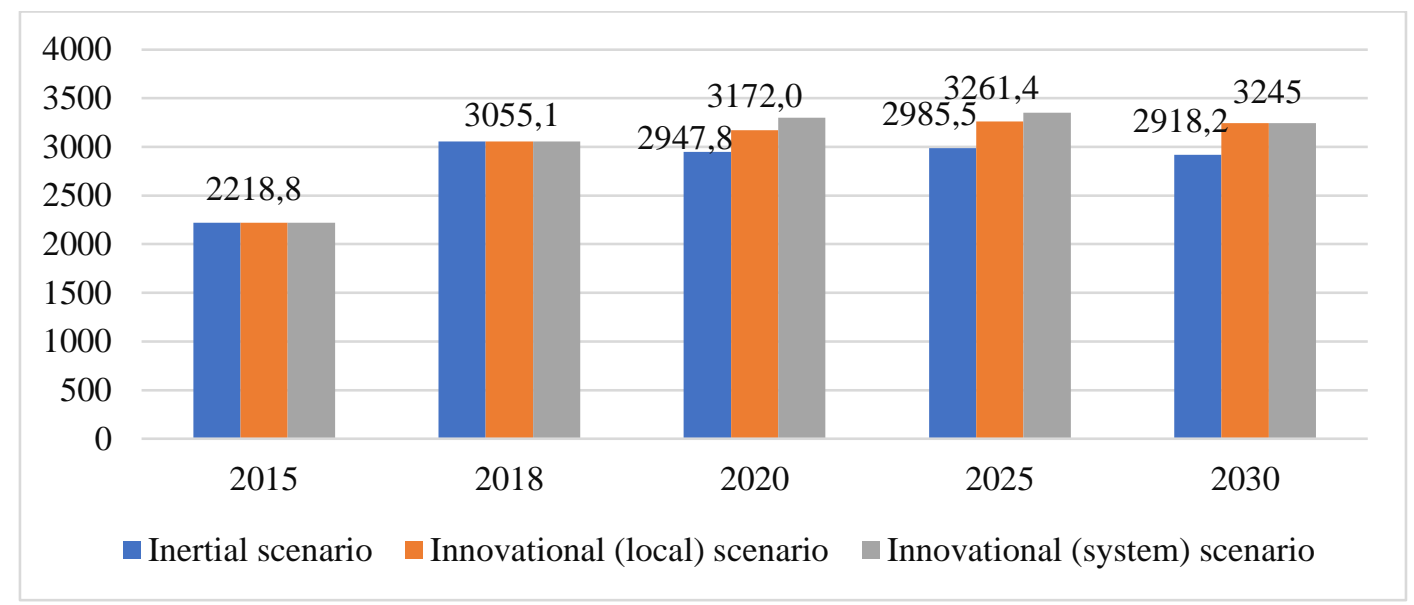

Figure 2. Forecast of Intraregional Milk Consumption in the Tambov Region for the Period of 2018 - 2030 by Strategic Development Scenarios

The intraregional demand for raw milk determines the minimum requirements for the agricultural production sector (Fig. 3). In the future, in the Tambov Region it is planned to expand the production facilities of pedigree farms up to 4,500 cattle places, and dairy farms in large holdings (with at least 400 cows) - up to 5,800 (Butylina, 2006). The forecast of gross milk production is calculated taking into account the marketability of milk and the current trends in the development of dairy cattle breeding in farms of various categories. The focus to the innovative way of the industry development can ensure the growth of gross milk production 3.2 times by 2030 as compared to 2015 , and by $60.3 \%$ as compared to the inertial scenario. 


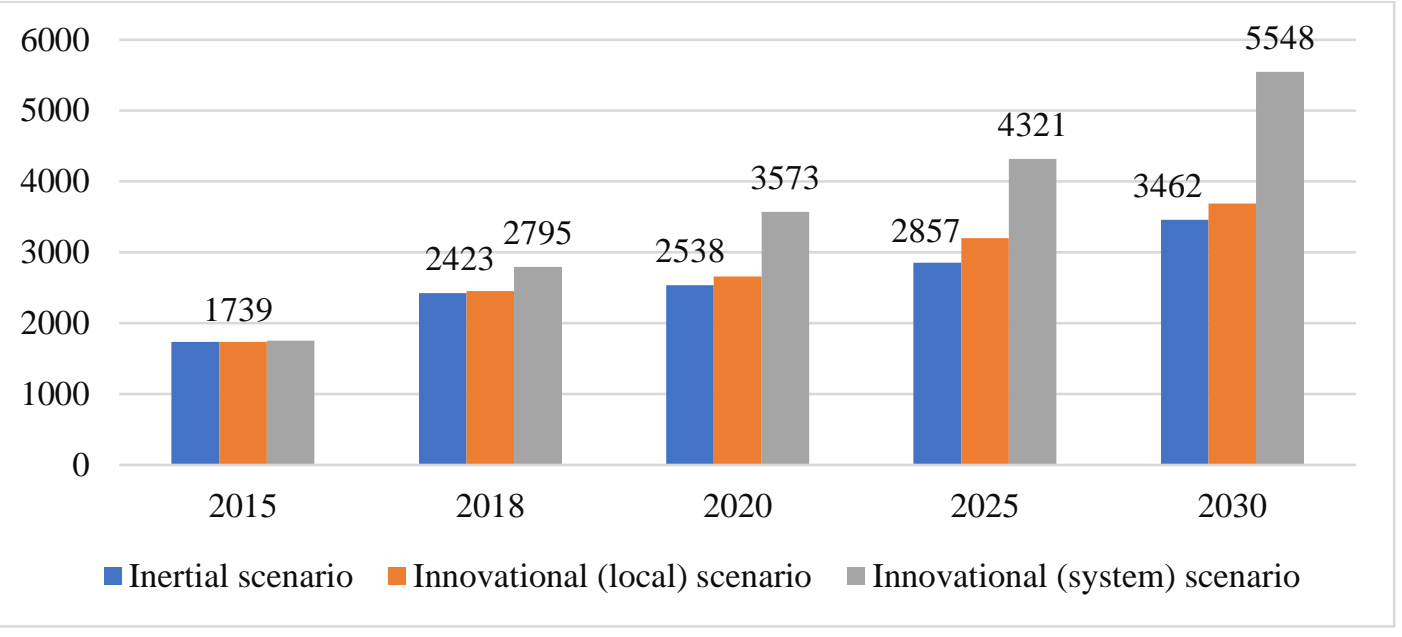

Figure 3. Forecast of Gross Milk Production in the Categories of Farms in the Tambov Region for the Period of 2018 - 2030 by Strategic Development Scenarios

\section{Discussion}

The milk production should be improved in farms of all categories on a high intensity basis, which provides for:

- Strengthening the breeding base of dairy cattle breeding,

- Improving the herd reproduction in agricultural organizations and peasant farms (farms), and

- Increasing the number of dairy cows in agricultural enterprises and peasant farms (farms).

According to the calculations, this will change the structure of milk production by categories of farms.

Thus, the establishment of 16 dairy complexes by 2030 and their functioning, as well as strengthening of the production base of peasant farms (farms) will make it possible to increase the share of agricultural organizations in the structure of the regional volume of milk production up to $47.1-49.1 \%$ and to occupy the largest share in it. The proportion of peasant farms (farms) in the structure of marketable milk production will increase from 14.0 - 17.9 $\%$ up to $37.3-40.9 \%$. The contribution of households to the formation of dairy resources in the region is assumed to radically change: their share in the structure of milk production will decrease from $50 \%$ in 2015 down to $10.3-15.6 \%$ in 2030 .

It is notable that under the modern economic conditions, the expanded reproduction of dairy cattle breeding in the Tambov Region is possible only if the profitability of milk 
production is ensured at the level of $30-$ $35 \%$. Taking into account the fact that dairy plants are also found in harsh "surviving" conditions and cannot often offer a reasonable purchase price for raw milk from the point of view of agricultural producers, the state can and must stabilize the situation by using direct and indirect support mechanisms (Butylina, 2006).

\section{Conclusion}

The development of agriculture in the Tambov Region has all chances for progressive changes in the strategic perspective. The considered forecast development scenarios have shown that the created potential is sufficient to implement the innovative approach to solving technological problems on improving the efficiency of agricultural production.

\section{References:}

Antsiferova, O.Yu. (2010). Transformatsiya printsipov kooperatsii i integratsii $\mathrm{V}$ protsesse razvitiya kooperatsionnyh i integratsionnyh otnosheniy [Transformation of cooperation and integration principles when developing cooperation and integration relations]. Bulletin of the Michurinsk State Agrarian University. Scientific-production journal, 2, 1-6. Antsiferova, O.Yu., Myagkova, E.A. (2015). Strategicheskoye planirovanie tseley ustoychivogo razvitiya selskogo hozyaystva [Strategic Planning of Sustainable Agricultural Development Goals]. International Agricultural Journal, 2, 29-31.

Bakinova, T.I., Darbakova, N.E., Kazakova, G.Y., Sangadzhieva, S.A., Darbakova, I.E. (2019). Information Support of Monitoring as a Tool of Ecological Optimization of Agricultural Land Use. Journal of Environmental Management and Tourism, 10(1), 195201.

Butylina, M.P. (2006). Razvitie kooperatsionnyh svyazey $\mathrm{V}$ sisteme regionalnogo APK [Development of cooperative relations in the regional agricultural system]: the dissertation for the degree of candidate of economic sciences. Saransk.

Chaliapin, I.P., Antsiferova, O.Yu., Myagkova, E.A. (2017). Strategicheskoye planirovaniye deyatelnosti predpriyatiya APK [Strategic planning of the activity of the agricultural enterprise]. St. Petersburg: Lan Publishing House. 
Khaidukova, E.S., Araslanov, R.K. (2019). Modern State Regulation of Migration Processes in the Northern Territories Taking into Account Factors of Social Attractiveness. Opcion, 35(19), 2956-2975.

Krivokora, Yu.N. (2006). Razvitie integratsii agrarnogo i promyshlennogo truda $\mathrm{v}$ usloviyah diversifikatsii proizvodstva [Development of integration of agricultural and industrial labor in the context of production diversification]. Economics of Agricultural and Processing Enterprises, 4, 47-49.

Ksenofontov, M.Yu., Jump, M.A., Sapova, N.N., Kozin, D.E. (2008). Stsenarnoe prognozirovanie kak instrument razrabotki strategii razvitiya selskogo hozyaystva [Scenario Forecasting as an Instrument for Developing an Agricultural Development Strategy]. Retrieved from: https://institutiones.com/strategies/1774 -scenarnoe-prognozirovanie-kakinstrument-razrabotki-strategiirazvitiya-selskogo-xozyajstva.html Mustafayeva, B., Kaltayeva, S., Saparova, A., Alimkulova, E., Kulbayeva, M. (2019). The Impact of Agricultural Environmental Pollutions on the Population's Quality of Life. The
Experience of Kazakhstan. Journal of Environmental Management and Tourism, 10(1), 161-170.

Ofitsialnyy sayt territorialnogo organa Federalnoy sluzhby gosudarstvennoy statistiki po Tambovskoy oblasti [The official website of the territorial body of the Federal State Statistics Service for the Tambov Region]. Retrieved from: http://tmb.gks.ru/wps/wcm/connect/ross tat_ts/tmb/ru/statistics/

Tolstoshein, K.V. (2015). Effektivnost realizatsii strategii razvitiya molochnogo skotovodstva Tambovskoy oblasti [Efficiency of Implementing the Strategy on Developing Dairy Cattle in the Tambov Region]. International Agricultural Journal, 4, 51-53.

Zakon Tambovskoy oblasti No. 246-Z. (June 4, 2018). "O Strategii sotsialnoekonomicheskogo razvitiya Tambovskoy oblasti do 2035 goda" [Law of the Tambov Region No. 246-Z "On the Strategy for the Social and Economic Development of the Tambov Region until 2035"]. Retrieved from: https://www.tambov.gov.ru/assets/files/ strategy/bc9bb531-f06a-4e4e -92acf39f924f8bfb.pdf

Zhildikbaeva, A.N., Sabirova, A.I., Pentaev, T., Omarbekova, A.D. (2019). Improving the Agricultural Land Use 
System in the Republic of Kazakhstan.

Journal of Environmental Management

and Tourism, 9(7), 1585-1592 